\title{
New Opportunities for the Horticultural Industry ${ }^{(1)}$
}

\author{
JANA SODERLUND(2)
}

\begin{abstract}
The last decade has witnessed an increasing focus on cities as they grow in population and shift in their function. Alongside, has been the emergence of the social movement of biophilic design. This approach to city design and the built environment is nature based and encourages the incorporation of nature, including plants, in a variety of principles called 'biophilic design'. Biophilic design is being rapidly adopted globally as the multiple benefits are consistently revealed and reinforced. This is presenting new opportunities for the horticultural industry as the use of plants in cities increases in evolving and creative ways. This paper outlines the evolution of the social movement of biophilic design, the principles of implementation that have emerged and the multiple benefits that ensue.
\end{abstract}

Keywords: Biophilic design, building integrated vegetation, green infrastructure, green roofs, green walls.

\section{INTRODUCTION}

Cities around the world are growing dramatically. More people now live in cities than in rural areas (LEHMANN, 2015, p. 1). "By 2030, 60 percent of the world population, or 4.9 billion people, are expected to live in urban areas" (GIRARDET, 2015, p.4). Human settlement has not occurred in such a way before. High fossil fuel and resource consumption has enabled this expansive urbanisation while contributing significantly to global warming and climate change (GIRADET, 2015; LEHMANN, 2015; HAAS and OLSSON, 2014). Yet, cities are not only expanding, they are changing in their roles and in their function. Deindustrialisation, increased mobility and a growing service sector have seen urban areas transform into post-industrial knowledge based economies of consumption rather than production (HAAS and OLSSON, 2014). Emerging from this shift in focus of cities' function is an evolving change in form: a change in the way buildings are being designed, constructed and landscaped.

\section{BIOPHILIA}

Typically, industrialised cities, with their focus on function, became harsh, engineered landscapes of paved surfaces and inner city urban canyons. Fromm (1964), and more recently, Salingaros and Masden (2008), recognised this, proposing that contemporary cities can be viewed as mechanistic, sterile, industrialised, commoditised and devoid of nature. Fromm (1964) also argued that urban dwellers were facing a disconnect from nature and loss of the psychological benefits that can ensue from a healthy human-nature relationship. To follow a positive, progressive pathway in life Fromm proposed that a love of life was necessary. He coined the term 'biophilia' to express this human-nature connection, with 'bio' meaning life and 'philia', the opposite of 'phobia', meaning attraction or love (Fromm, 1964). Significantly, years later another scholar, prominent sociobiologist, Edward Wilson, utilised Fromm's term biophilia to describe emotions which were provoked in a period of immersion in nature (WILSON, 1984). Wilson defined biophilia as the "innate tendency to focus on life and life-like processes" (WILSON, 1984, p.1). His book, Biophilia, presented a similar perspective to earlier conservationists such as Arne Naess (1989), though with a perception of the human connection to nature as an innate, biological need, not solely an inherent interdependence. Traditionally there have always been thinkers who have recognised human connection and interdependence with nature and encouraged others to do the same (LEOPOLD, 1949; NAESS, 1989). Illustrative descriptions of nature and ecosystems were set in the forests, rivers and natural areas, not in the cities. People travelled outside of the city to have a nature experience. Conservation, environmental or deep ecology movements tended to be 'anti' cities, focussed on protecting the nature that remained outside urban areas. Yet the shift in the function of cities, globalisation and the emergence of compact city theory (LEHMANN, 2015) is paving the way for a redefining of urbanites' relationship with nature, utilising the term biophilia introduced by Fromm in the 1960s.

\section{BIOPHILIC DESIGN}

Fromm's, and later Wilson's, suggestion of a biological need for nature which influences behaviour provoked interest and led to the assemblage of a group of interested scholars a decade later to discuss the concept which included Stephen Kellert, a socio-biologist. From this gathering, a hypothesis emerged, 'the Biophilia Hypothesis', with a book of the same name edited by Kellert and Wilson (KELLERT and WILSON, 1993). The hypothesis formalised Wilson's

(1) Received 03/08/2017 in and accepted in 12/08/2017

(2) Curtin University, Curtin University Sustainability Policy Institute (CUSP), Bentley, Australia.* jana.soderlund@curtin.edu.au

Licensed by CC BY 4.0 
earlier theory and proposed that biophilia, a love of life, is inherent and part of our species evolutionary heritage (KELLERT, 1993, p.21). The Biophilia Hypothesis received a positive reception amongst scholars but it was not until some years later, in 2007, that Kellert brought together a diverse group including academics, industry representatives and real estate investors who had shown a shared interest in increasing the opportunity for nature to find expression in urban design. Many ideas were discussed and design principles emerged. These resulted in a book called Biophilic Design (KELLERT et al., 2008) which introduced the concept and rationale for nature no longer being minimised in cities but recognised as having much to offer. Biophilic design is "the expression of the inherent human need to affiliate with nature in the design of the built environment" (KELLERT and HEERWAGEN, 2008, p.viii).

With technological advancements supported by academic research and literature, the inclusion of nature in cities has, in many cities, been rapidly, and globally, expanding. What began with a term coined by Fromm has attracted further investigation and development by interested people with common goals and a desire to enable a greater opportunity for urban dwellers to affiliate with nature, and all the benefits this provides, within the built environment. The focus on the human-nature connection is no longer relegated to conservationists and natural areas outside of cities; it is coming from urban inhabitants. A social movement based on biophilic design has evolved.

The movement appears to be supported by increasing urban population and changing city function which has led to a mutable dynamic and interplay between urban places and spaces. This recent and expanding transformation in human urban settlement is requiring a new approach to building cities. Cities need to be designed, planned, built and retrofitted to be sustainable and liveable (STOREY and KANG, 2015). Higher building density, urban canyons and paved surfaces modify local climate, particularly temperature, leading to a phenomenon known as the urban heat island effect (MILLS, 2015). This correlation between increasing global urban population, climate change and urban heat island effect, and the need for liveable, higher density cities is repeated throughout sustainability literature discussing cities and design (NEWMAN and JENNINGS, 2008; OWEN, 2009; STEINER, 2011). Within this framework, nature and biophilic design are finding a renewed status and recognition as essential components of a healthy, sustainable city (LEHMANN, 2015, p.20).

Global examples of biophilic design demonstrate that in many instances the initiative is not purely a functional response to a city's sustainability challenges. There is a motivation beyond the function. Indicators are there that a shift in the approach to the human-nature urban connection has occurred. The principles of biophilic design represent these newly emerging initiatives that are occurring in cities and presenting new opportunities for the horticulture industry.

\section{BIOPHILIC URBANISM}

Within the book, Biophilic Design, was a contribution by Tim Beatley which integrated the idea of biophilia at the urban scale as biophilic urbanism. It differs from just designing nature into the city by including consideration of the human- nature connection and the need for humans to have a daily interaction with nature. Beatley suggested that biophilic urbanism could contribute towards the creation of biophilic cities and is actively creating a global biophilic city network (BEATLEY, 2008; BEATLEY, 2017).

While researchers have been consolidating the social, environmental and economic benefits, other disciplines, particularly those related to urban design, have been refining the attributes of biophilic design into a workable palette for implementation.

Proponents of biophilic design have elaborated on design concepts, finding validity through experience, intuitive knowing and historical examples (HEERWAGEN and GREGORY, 2008; WILSON, 2008; KELLERT, 2008a). Authors in the book, Biophilic Design: The Theory, Science, and Practice of Bringing Buildings to Life (KELLERT et al., 2008), recognized the need to define the dimensions of biophilic design as the beginning of a tool kit for urban designers and developers. Heerwagen and Gregory (2008) categorized seven major attributes whereas Kellert (2008a) listed six elements with seventy design attributes.

Ryan et al. (2014) refined these design elements of biophilic design with supportive qualitative and quantitative research in both the physiological and the psychological. Ryan, together with Browning, recognizing previous design attribute lists were unwieldy and potentially confronting for urban designers, consolidated the design attributes to the following fourteen patterns within three categories.

A recent publication by Beatley, Handbook of Biophilic 
Table 1. Patterns of Biophilic Design

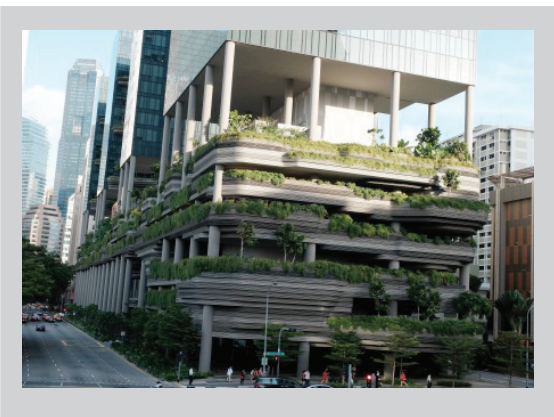

NATURE IN THE SPACE

incorporation of plants, water and animals into the built environment, especially with movement.

1. Visual connection with nature plants inside and out, green roofs and living walls, water, nature artwork

\section{2 .Non-visual connection with nature - sun patches, textured materials, bird sounds, weather, nature scents}

3. Non-rhythmic sensory stimuliclouds, shadows, nature sounds, water reflections

\section{Access to thermal and airflow}

variability - shade, radiant heat, seasonal vegetation

5. Presence of water - rivers, fountains, water walls, ponds, daylighted streams

6. Dynamic and diffuse light - light from different angles, ambient diffuse lighting, circadian lighting

\section{Connection with natural systems}

- seasonal patterning, wildlife habitats, diurnal patterns

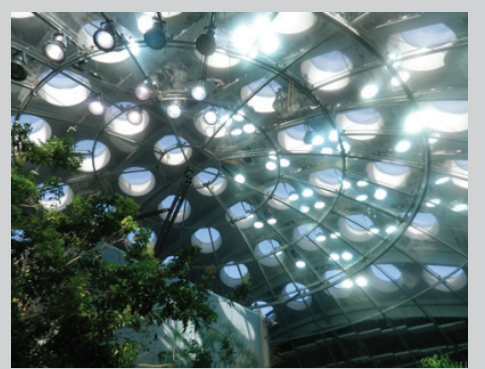

\section{NATURAL ANALOGUES}

one degree of separation away from true nature; patterns and materials that evoke nature.

8. Biomorphic forms and patterns organic building forms, structural systems (savannah effect)

\section{Material connection with nature}

- wood, earth and stone construction, natural colours

10. Complexity and order - fractal patterns, sky lines, plant selection and variety, material textures and colours

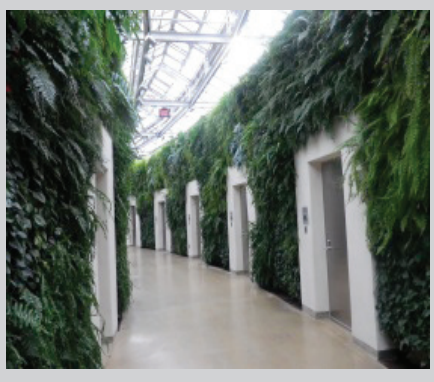

NATURE OF THE SPACE

the way humans respond psychologically and physiologically to different spatial configurations.

11. Prospect - views, balconies, $6 \mathrm{~m}$ and above focal lengths, open floor plans

12. Refuge - protected spaces, overhead canopies or lowered ceilings, places providing concealment

13. Mystery - winding paths, obscured features, flowing forms

14. Risk/Peril - floor to ceiling windows, water walks, high walk ways

(Adapted from Ryan et al.,2014)

City Planning and Design, drew on global initiatives of biophilic urbanism to inspire and demonstrate practical examples of biophilic design and design attributes (BEATLEY, 2017).

As seen in the Table 1 above many of the design attributes involve plants. Pattern number one, 'Visual Connection with Nature', contains innovative architectural and design features such as living walls and living roofs. These innovations are providing creative and expanding opportunities for horticulturalists around the world.
Green roofs have a historical place in urban design with the early sod roofs of European architecture, but new engineering techniques have developed to enable green roofs to become a major architectural feature of innovative buildings (TAN, 2013). Vertical greenery has also progressed from vine covered facades to vertical living walls since the aesthetic designs and constructions of innovative French botanist Patric Blanc (BEATLEY, 2011; TAN et al., 2009). As a result, a wide range of designs and methods for integrating nature into the built environment have emerged and continues to evolve. 


\section{LIVING GREEN WALLS AND GREEN FACADES}

Vertical living walls are adding a further dimension to cities around the world. Innovation and improved soil media are increasing the opportunities for inclusion of living walls both indoors and outdoors. Many of these have been stunning creative art works which draw attention and contribute to the aesthetics, while also bringing multiple social, environmental and economic benefits as outlined in section 7 below.
Patric Blanc is considered a pioneer of the contemporary living wall utilizing a panel system that is semi-hydroponic. These systems have the advantage of being light weight and able to be installed in large extensive panels on the outside of a building. Modular systems which are heavier, thicker and contain more growing medium can support a greater variety of plant species, be more robust and survive irrigation failures. Planter boxes with trailing plants, such as beautifully exhibited at Singapore's Park Royal Hotel, are also effective in creating a wall of living green and the associated benefits.

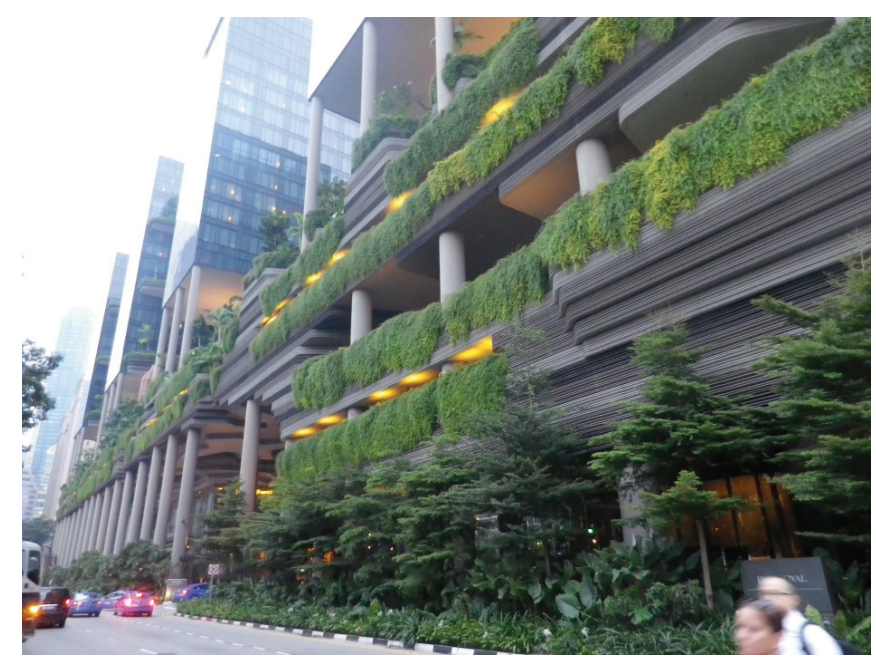

Figure 1. Park Royal Hotel, Singapore (source author)

Green façades are close to, but not attached, to the building. These tend to incorporate vines and creepers which deliver many of the benefits as attached living walls, but tend to be less expensive to install and easier to maintain. The creeper is typically grown from the ground at the base of the façade. Through the necessity of having to grow the green façade in situ, it can take longer to achieve the full benefits, particularly the insulating potential.
Indoor living walls can significantly improve air quality, particularly if utilizing technology pioneered by NASA and developed further by Guelph Humber University in Toronto. These walls are known as 'biofilters' and filter air through the soil medium where root rhizomes filter pollutants. The walls have been extremely effective, and popular, in improving indoor air quality in Toronto buildings. Similar research and outcomes are now happening in other cities such as Sydney, Australia, with the 'Breathing Wall' installed at Barangaroo.
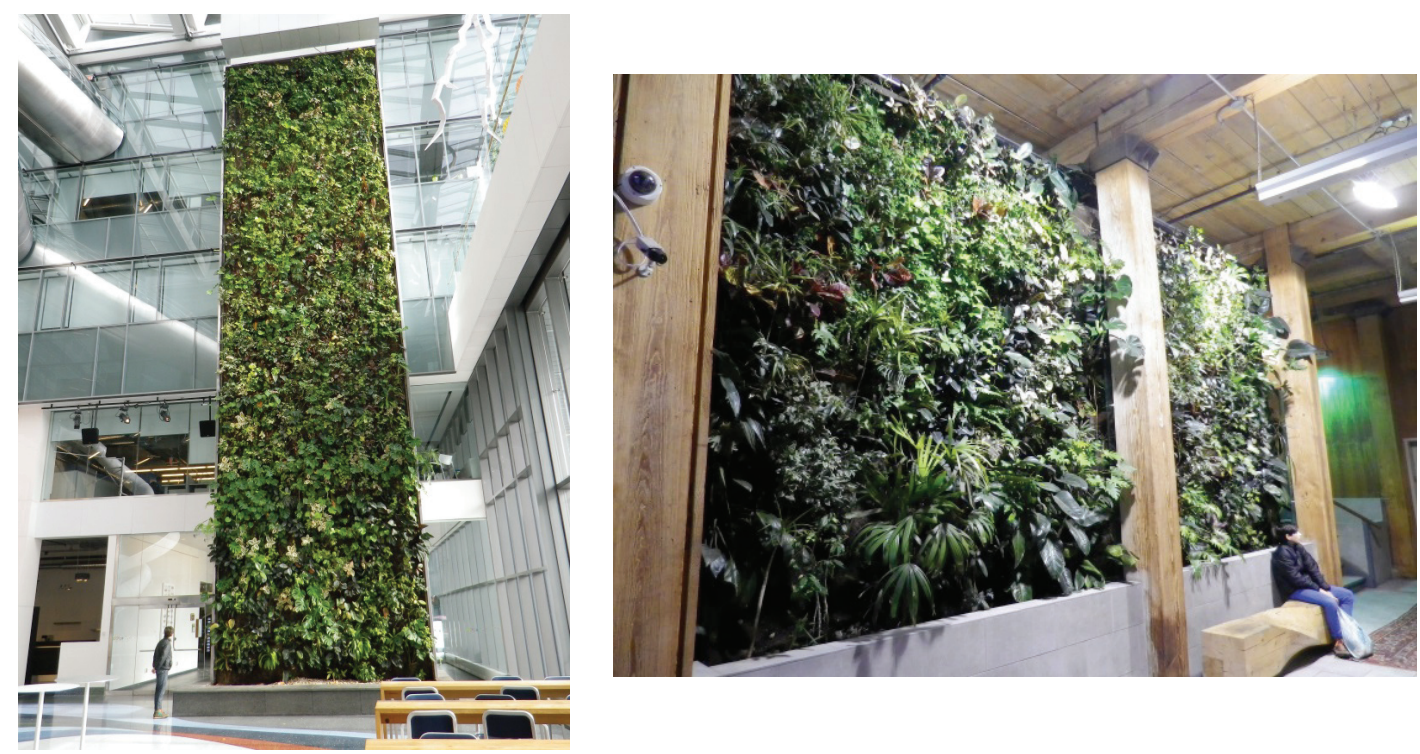

Figure 2 Biofilter indoor living walls, Toronto, Canada (source author) 


\section{VEGETATED (GREEN) ROOFS}

As the benefits of green roofs become more widely known and understood, there is a rapidly increasing number globally. North America is discovering that they are a very effective and popular option for managing storm water and reducing urban heat island effect. Basel, in Switzerland, has been installing green roofs for the past sixteen years with a focus on increasing biodiversity. Where there may be a sole initial driver for the green roof installation, the multiple benefits are discovered which then tends to lead to a ripple effect of further green roofs being installed in the surrounding area (SÖDERLUND and NEWMAN, 2015).

Chicago, for example, first conducted a green roof trial on their City Hall whose success led to incentives and regulations to encourage further green roofs in Chicago. The driver for this was the need to cool the city and reduce the urban heat island effect. By 2010, Chicago had 359 green roofs totalling 51 hectares and the Chicago City Hall green roof has become an icon for Chicago's sustainability movement (SÖDERLUND, 2016).

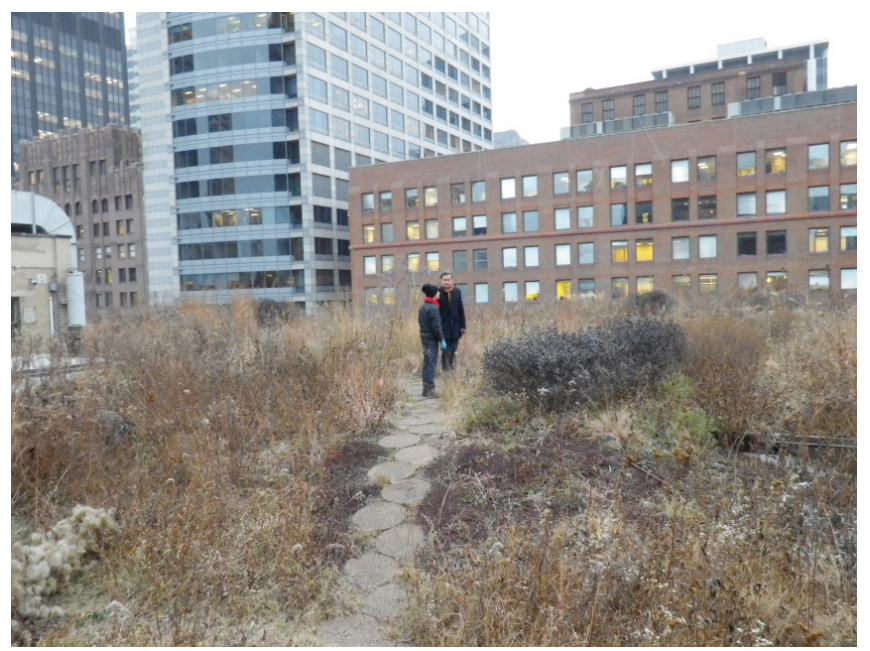

Figure 3. Chicago City Hall green roof in late autumn (Source author)

\section{Extensive and intensive}

There are two types of green roofs, intensive and extensive. Extensive tend to be larger with a shallower substrate and are the type most commonly referred to in the research. Intensive green roofs are smaller with more varied plant species in heights and function and are generally built with social amenity in mind rather than an environmental driver.
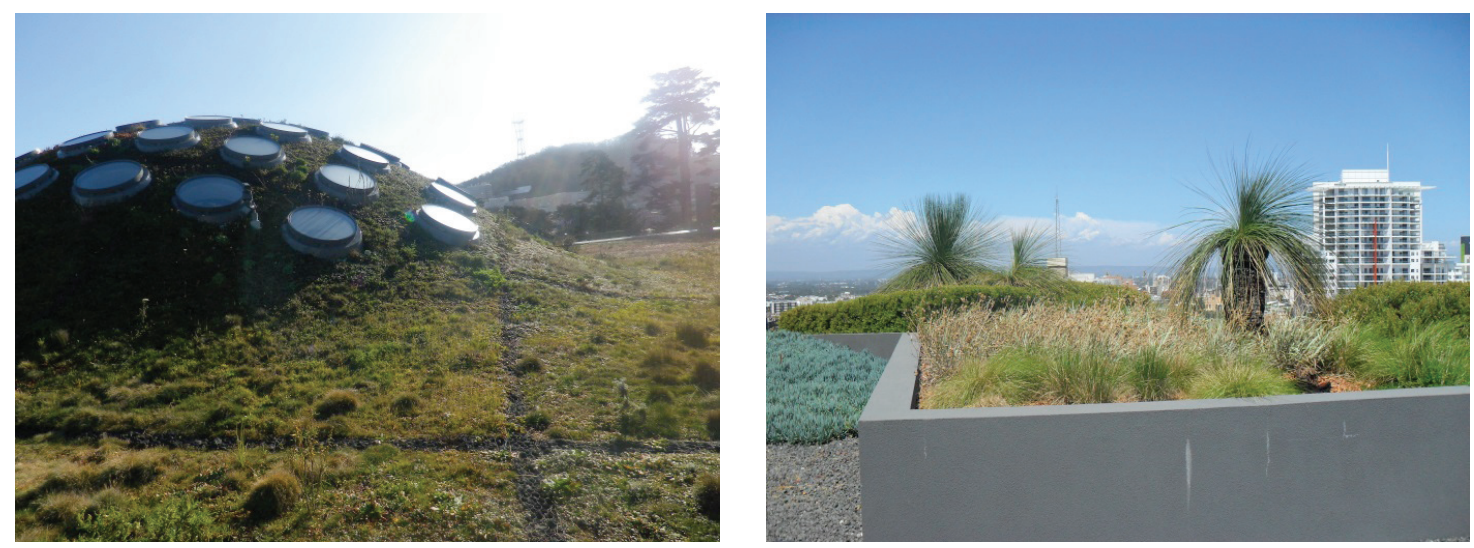

Figure 4. Extensive and intensive green roofs (source author)

Millenium Park in Chicago is an extensive 10 hectare green roof built over parking lots and an end of line train station that has resulted in increasing tourism and further development bringing \$3-5 billion economic benefit to the area (SÖDERLUND, 2016). 


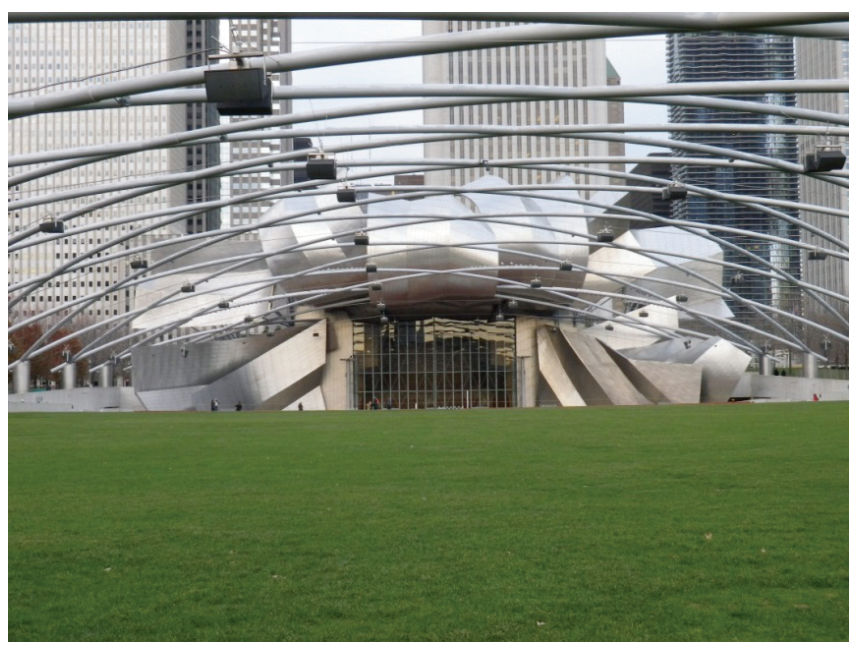

Figure 5. Millenium Park green roof Chicago (source author)

Green roofs need not be flat but may be sculpted for aesthetics or significance. The extensive green roof on the California Academy of Science in San Francisco has seven mounds modelled on the seven roofs of the city and planted with sedums. Studies by Loder (2014) on varying types of plant species and the social responses they bring revealed that 'wilder' roofs may lead to increased creative thinking. It also showed that responses varied with cities and personal experience (LODER, 2014) with some people preferring more sculpted sedum plantings over the wilder prairie style such as the Chicago City hall roof.
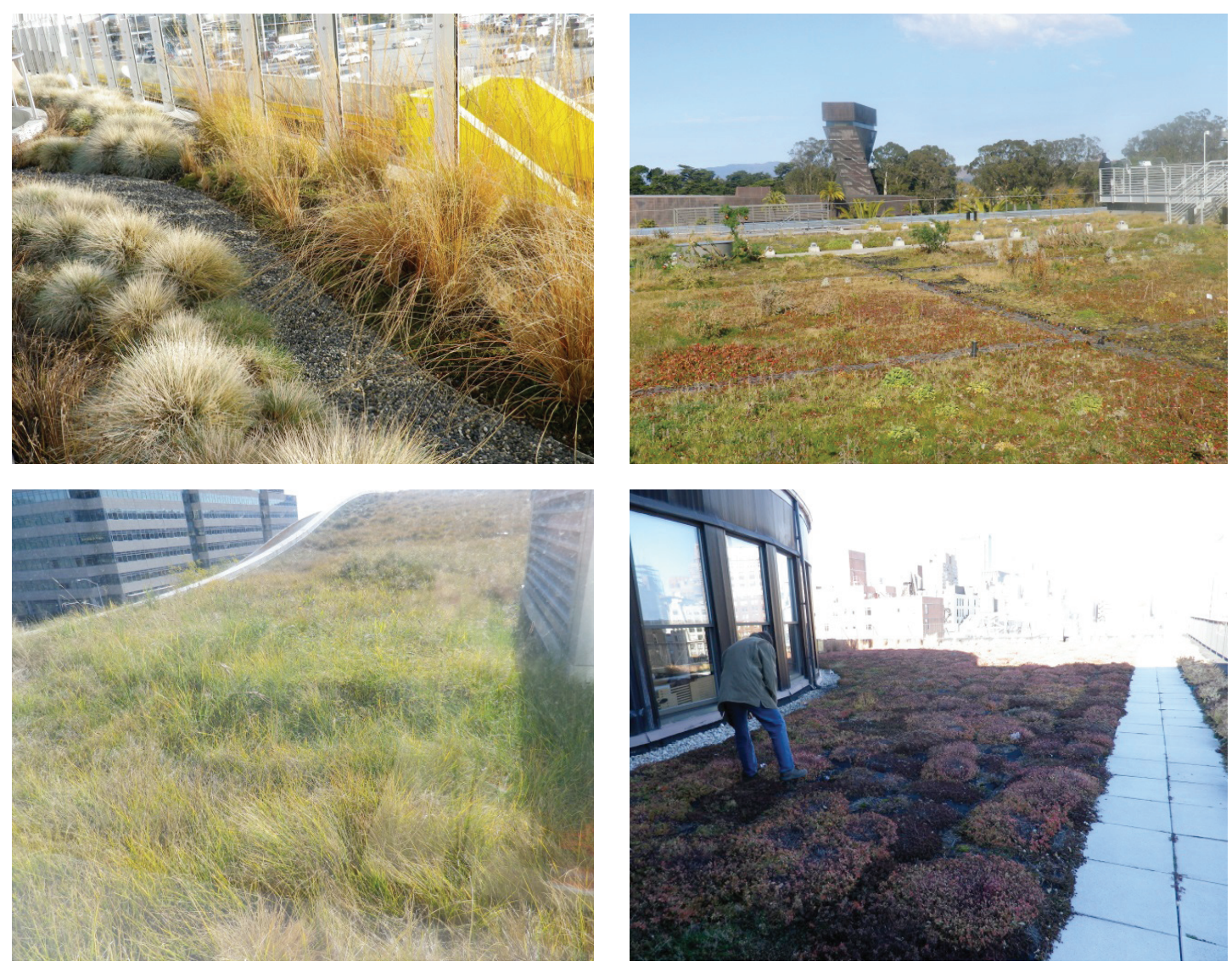

Figure 6. Comparison of prairie (left) to sedum (right) (source author) 
Policy has been successful, particularly in the implementation of green roofs in global cities, by incorporating the option for a green roof in sustainability standards, or by providing incentives and rebates and by regulation.

Germany began with incentives in 1983 followed by Basel, Switzerland, in 2000. Both countries currently have a high number of green roofs and it is now an accepted form of practice. Washington initiated a green roof rebate program in 2005 and, as part of their Sustainable DC strategy aims to have 20 million sq $\mathrm{ft}$ green roofs by 2020. Many cities have initiated some form of incentives or regulations encouraging green roof construction in their cities. Globally, there is a growing tool kit of options for policy.

As implementation of vegetated roofs rapidly expands around the world, the opportunity for research on these roofs in various climatic conditions also increases. What the research is revealing is the multiple benefits which can result with installing vegetated (green) roofs. Decreased biodiversity, urban heat island effects and pollution have become current and urgent environmental issues that challenge the resilience of cities, alongside social problems such as high stress and obesity. Green roofs can offer mitigation to some of these current city ills as well as increase a city's aesthetics which in turn can trigger a greater sense of connection to place in city dwellers.

In the last decade, research on the outcomes of biophilic design, combined with improved monitoring technologies, has enabled benefits to be both qualified and quantified. Of particular interest has been the human and nature connection and the benefits of human exposure to direct greenery.

\section{THE MULTIPLE BENEFITS}

\section{Environmental benefits}

In the last decade green roofs, and to a lesser extent living walls, have attracted a lot of research on the benefits that they can bring, particularly the environmental benefits. As both of these have technologically developed, a range of environmental benefits have been evaluated including improvements to water, air, biodiversity and heat.

Water management: ability to retain storm water onsite, slow runoff rates, filter water (ANDERS and WALKER, 2011; GREGOIRE and CLAUSEN, 2011; [1].

- Including reduction in water pollution: (GREGOIRE and CLAUSEN, 2011; SEIDL et al., 2013; ROWE, 2011).

Air pollution: (LEVIN, 2014; PEGAS et al., 2012; WOLVERTON et al., 1984).

- carbon reduction: (AKBARI 2002; CAREY, 2013; LEUNG et al., 2011; MIYAWAKI, 1998; OTTELE et al., 2011; SHEWEKA and MAGDY, 2011)

- phytoremediation: (CAREY, 2013; LEUNG et al., 2011; OTTELE et al., 2010; PUGH et al., 2012; SHEWEKA and MAGDY, 2011).
Biodiversity: both ecosystem services and species retention and regeneration: (BAUMANN, 2006; BRENNEISAN, 2006; COOK-PATTON and BAUERLE, 2012; GRANT, 2006; MADRE et al., 2014; NEWMAN, 2014)

Reduction of urban heat island effect (AKBARI, 2002; KONTOLEON and EUMORFOPOULOU, 2010; WONG et al., 2010)

Reduction of energy consumption (AKBARI, 2002; CHENG et al., 2010; JAFFAL et al., 2012; HONGMING and JIM, 2010; LEUNG et al., 2011 SHEWEKA and MOHAMED, 2012; SPROUL et al., 2014; SUSCA et al., 2010; ADHIKARI et al., 2016)

\section{Social benefits}

Access to greenery, or even a view of a vegetated roof, can bring social benefits. These have been recognized by corporations such as Google and the Bank of America. The Manhattan branch of the Bank of America paid for the greening of the surrounding rooftops with the understanding and economic results of high quality employees, greater productivity with decreased absenteeism and higher employee retainment. In the last 30-40 years technological advancements in both psychological and physiological testing have enabled further exploration and testing on whether there is an innate human relationship with nature which is the fundamental rationale for biophilic urbanism. This has led to a substantial quantity of global research revealing significant social benefits for humans with some access to nature such as increased well-being and health, faster healing rates and faster attention restoration. These are summarized below:

Improved mental health: (ULRICH, 1979; ULRICH et al., 1991; BERMAN et al., 2012; TYRVÄINEN et al., 2014).

Reduced stress: (LI et al., 2011; BERMAN et al., 2012; MATSUNAGA et al., 2011; PARK et al., 2010; TYRVÄINEN et al., 2014; BERMAN et al., 2008; IKEI et al., 2014; HAGERHALL et al., 2012; TAYLOR, 2006).

Attention restoration: (KAPLAN, 1995; BERTO, 2005; TENNGART et al., 2008; RAANAAS, 2011).

Increased wellbeing: (LI et al., 2011; BERMAN et al., 2012; TYRVÄINEN et al., 2014; BERMAN et al., 2008; IKEI et al., 2014; HAGERHALL et al., 2012).

Decreased violence and crime: (KUO and SULLIVAN, 2001).

Faster healing rates in hospitals: (ULRICH, 1984; PARK and MATTSON, 2008; MOORE, 1981).

Greater altruistic behaviour: (GUĖGUEN and STEFAN, 2014).

\section{Economic benefits}

The socio-psychological and environmental benefits are likely to combine to contribute to significant economic benefits as set out in the figure below. If humans are functioning better and their environment is working better then the human economy is going to be more productive and efficient. 
Research has provided the quantifiable data that has enabled the economic case to be made, yet the research has tended to focus on the economics of either an individual benefit or a few connected benefits. Yet there are multiple benefits. The economic gains to be made from environmental benefits such as reduced energy costs, extended building life, and decreased water management costs are apparent. Extrapolating the quantitative figures to support this is particular to location and local costs, but presents an area of research needing further attention.

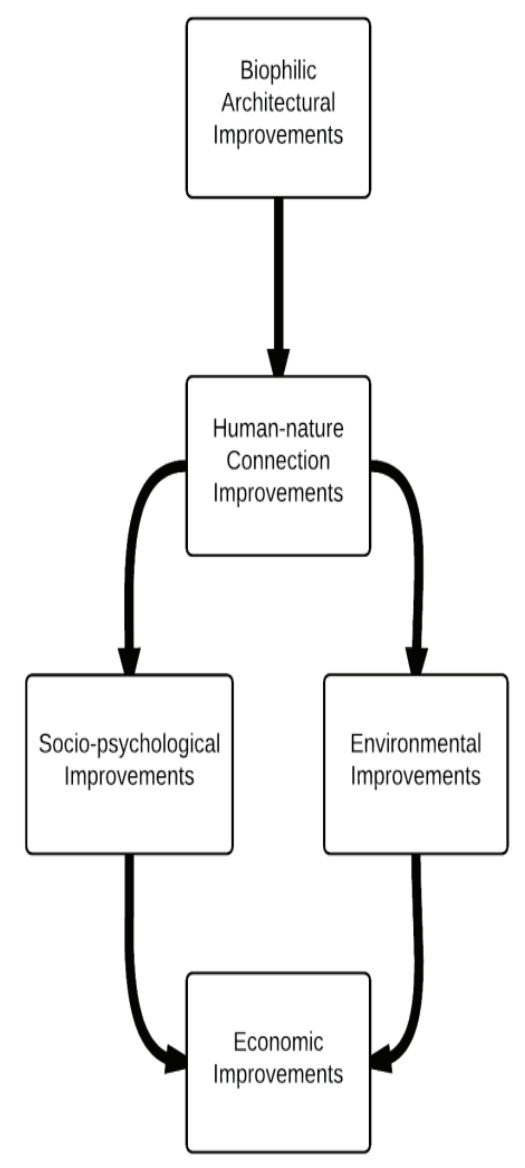

Figure 7. Biophilic architectural benefit flow (source author)

Economic benefits are summarized:

- Reduced energy costs: see previous

- Extending building life: see previous

- Decreased water management costs: see previous

- Increased worker productivity: (BROWNING et al., 2012; ERWINE and HESCHONG, 2000; HEERWAGEN, 2000; HESCHONG, 2002).

- Health and healing benefits: (BEAUCHEMIN and HAYS, 1996; BENEDETTI et al., 2001; HEERWAGEN, 2000; MATSUNAGA et al., 2011; PARK and MATTSON, 2008; SINGH et al., 2010; ULRICH, 2006).

- Increased retail potential: (BRENGMAN et al., 2012; ERWINE and HESCHONG, 2000; JOYE et al., 2010; WOLF, 2005)

- Decreased violence and crime: (BROWNING et al., 2012; KUO and SULLIVAN, 2001).

- Increased property value and employee attraction: (BEATLEY, 2011; BENSON et al., 1998; BROWNING et al., 2012; EICHHOLTZ et al., 2010; HEERWAGEN, 2000).
- Increased liveability enabling higher density and reduced footprint: (NEWMAN and KENWORTHY, 2015).

\section{CONCLUSIONS}

The emergence of biophilic design has been timely. It is the outcome of a confluence of discoveries and events driven by the need to respond to urban crises. Coinciding with this have been technological discoveries and advancements that have enabled the progression. Not only have there been advancements in roof membranes and green wall technologies, there have also been technological advancements for designers, providing the capacity for computer modelling and graphics to interpret and visually display their designs. Horticulturalists, engineers, architects can then utilize computer modeling to translate these designs into working plans.

Again technological innovations and scientific discoveries have contributed to the expansion of 
the knowledge base of people's physiological and psychological responses to nature. From early biological and biochemical discoveries, there has been a continual improvement in the ability to measure human responses to biophilic design and in knowing what the responses are and what to measure. These technological advancements and improved measuring capabilities have enabled the quantifiable economic rationale to begin to be compiled.

The ability to increase nature in our cities through creative thinking, innovative technologies and the principles of biophilic design, driven by the need to address urban issues such as urban heat and increasing density, is providing not only new opportunities for the horticultural industry, but the necessity for horticulturalists to embrace these new opportunities, contributing their knowledge and expertise in creative new ways.

\section{REFERENCES}

ADHIKARI, A.; SAVVAS, W.; DIXON, I. Green roofs for energy efficiency - a simulation study in Australian climates. Environment Design Guide, v.88, p.1-23, 2016.

AKBARI, H. Shade trees reduce building energy use and $\mathrm{CO} 2$ emissions from power plants. Environmental Pollution, v.116, Supplement 1, S119-S126, 2002. Doi: http://dx.doi.org/10.1016/S0269-7491(01)00264-0

ANDERS, R.M.; WALKER, J.B. Green roof stormwater performance in a southeastern US climate. Paper presented at the 9th Annual Green Roof \& Wall Conference, Philadelphia, US. 2011.

BAUMANN, N. Ground-Nesting birds on green roofs in Switzerland: Preliminary Observations. Urban habitats, v.4, p.1, 2006.

BEATLEY, T. Toward Biophilic Cities: Strategies for Integrating Nature into Urban Design. In: KELLERT, S.R.; HEERWAGEN, J.H.; MADOR, M.L. (Eds.). Biophilic Design: The theory, science, and practice of bringing buildings to life. New Jersey: John Wiley \& Sons, 2008. pp. $227-241$

BEATLEY, T. Biophilic cities: Integrating nature into urban design and planning. Washington, DC: Island Press, 2011.

BEATLEY, T. Handbook of Biophilic City Planning \& Design. Washington, DC: Island Press, 2017.

BEAUCHEMIN, K.M.; HAYS, P. Sunny hospital rooms expedite recovery from severe and refractory depressions. Journal of Affective Disorders, v.40, n.1-2, p.49-51, 1996. Doi: http://dx.doi.org/10.1016/0165-0327(96)00040-7
BENEDETTI, F.; COLOMBO, C.; BARBINI, B.; CAMPORI, E.; SMERALDI, E. Morning sunlight reduces length of hospitalization in bipolar depression. Journal of Affective Disorders, v.62, n.3, p.221-223, 2001. Doi: http://dx.doi.org/10.1016/S0165-0327(00)00149-X

BENSON, E.D.; HANSEN, J.L.; SCHWARTZ JR, A.L.; SMERSH, G.T. Pricing Residential Amenities: The Value of a View. Journal of Real Estate Finance \& Economics, v.16, n.1, p.55-73, 1998. Doi: 10.1023/A:1007785315925

BERMAN, M.G. ; JONIDES, J. ; KAPLAN, S. The Cognitive Benefits of Interacting with Nature. Psychological Science, v.19, n.12, p.1207-1212, 2008. Doi: $10.2307 / 40064866$

BERMAN, M.G.; KROSS, E.; KRPAN, K.M.; ASKREN, M.K.; BURSON, A.; DELDIN, P.J.; KAPLAN, S.;SHERDELL, L.; GOTLIB, I.H.; JONIDES, J. Interacting with nature improves cognition and affect for individuals with depression. Journal of Affective Disorders, v.140, n.3, p.300-305, 2012. Doi: http://dx.doi.org/10.1016/j. jad.2012.03.012

BERTO, R. Exposure to restorative environments helps restore attentional capacity. Journal of Environmental Psychology, v.25, n.3, p.249-259, 2005. Doi: http://dx.doi. org/10.1016/j.jenvp.2005.07.001

BRENGMAN, M.; WILLEMS, K.; JOYE, Y. The Impact of In Store Greenery on Customers. Psychology \& Marketing, v.29, n.11, p.807-821, 2012. Doi: 10.1002/ mar.20566

BRENNEISAN, S. Space for urban wildlife: Designing green roofs as habitats in Switzerland. Urban habitats, v.4, n.1, 2006.

BROWNING, B.; GARVIN, C.; RYAN, C.; KALLIANPURKAR, N.; LABRUTO, L.; WATSON, S.; KNOP, T. The Economics of Biophilia - Why Designing with Nature in Mind Makes Financial Sense, 2012. Retrieved from Terrapin Bright Green website: http://www. terrapinbrightgreen.com/report/economics-of-biophilia/

CAREY, P. A Guide to phytoremediation: a symbiotic relationship with plants, water \& living architecture, 2013. Available: Greenroofs.com., 2014, from http:// www.greenroofs.com/content/Phytoremediation-ASymbiotic-Relationship-with-Plants-Water-and-LivingArchitecture.htm

CHENG, C.Y.; CHEUNG, K.K.S.; CHU, L.M. Thermal performance of a vegetated cladding system on facade walls. Building and Environment, v.45, n.8, p.1779-1787, 2010. Doi: http://dx.doi.org/10.1016/j.buildenv.2010.02.005 
COOK-PATTON, S.C.; BAUERLE, T.L. Potential benefits of plant diversity on vegetated roofs: A literature review. Journal of Environmental Management, v.106, p.85-92, 2012. Doi: http://dx.doi.org/10.1016/j. jenvman.2012.04.003

EICHHOLTZ, P.; KOK, N.; QUIGLEY, J. Doing Well by Doing Good? Green Office Buildings. American Economic Review, v.100, n.5, p.2492-2509, 2010. Doi: 10.1257/aer.100.5.2492

ERWINE, B., HESCHONG, L. Daylight: healthy, wealthy \& wise. Architectural Lighting, v.15, n.2, p.98, 2000

FROMM, E. The heart of man. New York: Harper and Row, 1964.

GIRARDET, H. Creating regenerative cities. Oxon: Routledge, 2015.

GRANT, G. Extensive Green Roofs in London. Urban habitats, v.4, n.1, p.51-65, 2006.

GREGOIRE, B.G.; CLAUSEN, J.C. Effect of a modular extensive green roof on stormwater runoff and water quality. Ecological Engineering, v.37, n.6, p.963-969, 2011. doi: http://dx.doi.org/10.1016/j.ecoleng.2011.02.004

GUÉGUEN, N.; STEFAN, J. "Green Altruism": short immersion in natural green environments and helping behavior. Environment and Behavior, v.48, n.2, p.324342, 2014. Doi: 10.1177/0013916514536576

HAAS, T.; OLSSON, K. Transmutation and Reinvention of Public Spaces Through Ideals of Urban Planning and Design. Space and Culture, v.17, n.1, p.59-68, 2014.

HAGERHALL, C.; LAIKE, T.; TAYLOR, R.; KÜLLER, M.; MARCHESCHI, E.; BOYDSTON, C. Human eeg responses to exact and statistical fractal patterns. In: IAPS 22, 2012.

HEERWAGEN, J.; GREGORY, B. Biophilia and sensory aesthetics. In: KELLERT, S.R. et al., (Eds.), Biophilic Design: The theory, science, and practice of bringing buildings to life. New Jersey: John Wiley \& Sons, 2008. pp.227-241.

HEERWAGEN, J. Green buildings, organizational success and occupant productivity. Building Research and Information, v.28, n.5-6, p.353-367, 2000.

HESCHONG, L. Daylighting and human performance. ASHRAE Journal, v.44, n.6, p.65, 2002
HONGMING, H.; JIM, C.Y. Simulation of thermodynamic transmission in green roof ecosystem. Ecological Modelling, v.221, n.24, p.2949-2958, 2010. Doi: 10.1016/j. ecolmodel.2010.09.002

IKEI, H.; KOMATSU, M.; SONG, C.R.; HIMORO, E.; MIYAZAKI, Y. The physiological and psychological relaxing effects of viewing rose flowers in office workers. Journal of Physiological Anthropology, v.33, n.6, p.1-5 2014. Doi: 10.1186/1880-6805-33-6

JAFFAL， I.; OULDBOUKHITINE, S.E.; BELARBI, R. A comprehensive study of the impact of green roofs on building energy performance. Renewable Energy, v.43, p.157-164, 2012. Doi: http://dx.doi.org/10.1016/j. renene.2011.12.004

JOYE, Y.; WILLEMS, K.; BRENGMAN, M.; WOLF, $\mathrm{K}$. The effects of urban retail greenery on consumer experience: Reviewing the evidence from a restorative perspective. Urban Forestry and Urban Greening, v.9, n.1, p.57-64, 2010. Doi: 10.1016/j.ufug.2009.10.001

KAPLAN, S. The restorative benefits of nature: Toward an integrative framework. Journal of Environmental Psychology, v.15, n.3, p.169-182, 1995. Doi: http://dx.doi. org/10.1016/0272-4944(95)90001-2

KELLERT, S.R.; HEERWAGEN, J. Preface. In: KELLERT, S.R.; HEERWAGEN, J.; MADOR, M. L. (Eds.). Biophilic design: the theory, science, and practice of bringing buildings to life. Hoboken: Wiley, 2008.

KELLERT, S.R. Introduction. In: KELLERT, S.R.; WILSON, E.O. (Eds.). The biophilia hypothesis. Washington: Island Press, 1993.

KELLERT, S.R. Dimensions, elements, and attributes of biophilic design. In: KELLERT, S.R.; WILSON, E.O. (Eds.). Biophilic design. New Jersey: John Wiley and Sons, 2008a. pp. 3-19.

KELlERT, S.R.; WILSON, E.O. (Eds.) The biophilia hypothesis. Washington: Island Press, 1993.

KELLERT, S.R., HEERWAGEN, J.; MADOR, M. L. (Eds.). Biophilic design: the theory, science, and practice of bringing buildings to life. Hoboken: Wiley, 2008.

KONTOLEON, K.J.; EUMORFOPOULOU, E.A. The effect of the orientation and proportion of a plant-covered wall layer on the thermal performance of a building zone. Building and Environment, v.45, n.5, p.1287-1303, 2010. Doi: http://dx.doi.org/10.1016/j.buildenv.2009.11.013 
KUO, F.E.; SULLIVAN, W.C. Environment and crime in the inner city - Does vegetation reduce crime? Environmental Behavior, v.33, n.3, p.343-367, 2001.

LEHMANN, S. Low carbon cities: More than just buildings. In: LEHMANN S. Low carbon cities. Oxon: Routledge, 2015.

LEOPOLD, A. A sand county almanac. Oxford: Oxford University Press, 1949.

LEUNG, D.Y.C.; TSUI, J.Y.; CHEN, F.; YIP, W.K.; VRIJMOED, L.P.; LIU, C.H. Effects of Urban Vegetation on Urban Air Quality. Landscape Research, v.36, n.2, p.173-188, 2011. Doi: 10.1080/01426397.2010.547570

LEVIN, H. Can house plants solve indoor air quality problems? Retrieved 21/07/14, 2014, from http://www. practicalasthma.net/pages/topics/aaplants.htm

LI, Q.; OTSUKA, T.; KOBAYASHI, M.; WAKAYAMA, Y.; INAGAKI, H.; KATSUMATA, M.; HIRATA, K.; SHIMIZU, T.; SUZUKI, H.; KAWADA, T.; KAGAWA, T. (2011). Acute effects of walking in forest environments on cardiovascular and metabolic parameters. European Journal of Applied Physiology, v.111, n.11, p.2845-2853. doi: 10.1007/s00421-011-1918-z

LODER, A. 'There's a meadow outside my workplace': A phenomenological exploration of aesthetics and green roofs in Chicago and Toronto. Landscape and Urban Planning, v.126, p.94-106, 2014. Doi: http://dx.doi.org/10.1016/j. landurbplan.2014.01.008

MADRE, F.; VERGNES, A.; MACHON, N.; CLERGEAU, P. Green roofs as habitats for wild plant species in urban landscapes: First insights from a large-scale sampling. Landscape and Urban Planning, v.122, p.100-107, 2014. Doi: http://dx.doi.org/10.1016/j.landurbplan.2013.11.012

MATSUNAGA, K.; PARK, B.J.; KOBAYASHI, H.; MIYAZAKI, Y. Physiologically relaxing effect of a hospital rooftop forest on older women requiring care. Journal of the American Geriatrics Society, v.59, n.11, p.2162-2163, 2011. Doi: 10.1111/j.1532-5415.2011.03651.x

MILLS, G. The urban heat island and low carbon cities. In: LEHMANN, S. Low carbon cities. Oxon: Routledge, 2015.

MIYAWAKI, A. Restoration of urban green environments based on the theories of vegetation ecology. Ecological Engineering, v.11, n.1-4, p.157-165, 1998. Doi: http:// dx.doi.org/10.1016/S0925-8574(98)00033-0

MOORE, E.O. A prison environment's effect on health care service demands. Journal of environmental systems, v.11, n.1, p.17-34, 1981.
NAESS, A. Ecology, community, and lifestyle: outline of an ecosophy / Arne Naess. Cambridge: Cambridge University Press, 1989.

NEWMAN, P.; JENNINGS, I. Cities as sustainable ecosystems. Washington: Island Press, 2008.

NEWMAN, P. Biophilic urbanism: a case study on Singapore. Australian Planner, v.51, n.1, p.47-65, 2014. Doi: $10.1080 / 07293682.2013 .790832$

NEWMAN, P.; KENWORTHY, J. The End of Automobile Dependence: How Cities are Moving Beyond Car-Based Planning. New York: Island Press, 2015.

OTTELÉ, M.; PERINI, K.; FRAAIJ, A.L.A.; HAAS, E.M.; RAITERI, R. Comparative life cycle analysis for green façades and living wall systems. Energy and Buildings, v.43, n.12, p.3419-3429, 2011. Doi: http://dx.doi. org/10.1016/j.enbuild.2011.09.010

OTTELÉ, M.; VAN BOHEMEN, H.D.; FRAAIJ, A.L.A. Quantifying the deposition of particulate matter on climber vegetation on living walls. Ecological Engineering, v.36, n.2, p.154-162, 2010. Ddoi: http://dx.doi.org/10.1016/j. ecoleng.2009.02.007

OWEN, D. Green metropolis. New York: Penguin Group, 2009.

PARK, B.J.; TSUNETSUGU, Y.; KASETANI, T.; KAGAWA, T.; MIYAZAKI, Y. The physiological effects of Shinrin-yoku (taking in the forest atmosphere or forest bathing): evidence from field experiments in 24 forests across Japan. Environmental Health and Preventive Medicine, v.15, n.1, p.18-26, 2010. Doi: http://dx.doi. org/10.1007/s12199-009-0086-9

PARK, S.H.; MATTSON, R.H. Effects of flowering and foliage plants in hospital rooms on patients recovering from abdominal surgery. HortTechnology, v.18, n.4, p.563-568, 2008.

PEGAS, P.N.;ALVES, C.A.; NUNES, T.; BATE-EPEY,E.F.; EVTYUGINA, M.; PIO, C.A. Could Houseplants improve indoor air quality in schools? Journal of Toxicology and Environmental Health, Part A, v.75, n.22-23, p.13711380, 2012. Doi: 10.1080/15287394.2012.721169

PUGH, T.A.M.; MACKENZIE, A.R.; WHYATT, J.D.; HEWITT, C.N. Effectiveness of green infrastructure for improvement of air quality in urban street canyons. Environmental Science and Technology, v.46, n.14, p.7692-7699, 2012. Doi: 10.1021/es300826 
RAANAAS, R.K.; EVENSEN, K.H.; RICH, D.; SJØSTRØM, G.; PATIL, G. Benefits of indoor plants on attention capacity in an office setting. Journal of Environmental Psychology, v.31, n.1, p.99-105, 2011. Doi: http://dx.doi.org/10.1016/j.jenvp.2010.11.005

ROWE, D.B. Green roofs as a means of pollution abatement. Environmental Pollution, v.159, n.8-9, p.2100-2110, 2011. Doi: http://dx.doi.org/10.1016/j.envpol.2010.10.029

RYAN, C.O.; BROWNING, W.O.; CLANCY, J.O.; ANDREWS, S.L.; KALLIANPURKAR, N.B. Biophilic design patterns: eEmerging nature-based parameters for health and well-being in the built environment. ArchNet International Journal of Architectural Research, v.8, n.2, p.62-76, 2014.

SALINGAROS, N.A.; MASDEN, K.G. Neuroscience, the natural environment, and building design. In: KELLERT, N.S.R.; HEERWAGEN J.H.; MADOR M.L. Biophilic design: the theory, science, and practice of bringing buildings to life. New Jersey: John Wiley \& Sons, 2008. pp.59-83.

SEIDL, M.; GROMAIRE, M.C.; SAAD, M.; GOUVELLO, B. Effect of substrate depth and rain-event history on the pollutant abatement of green roofs. Environmental Pollution, v.183, p.195-203, 2013. Doi: http://dx.doi. org/10.1016/j.envpol.2013.05.026

SHEWEKA, S.M.; MOHAMED, N.M. Green Facades as a New Sustainable Approach Towards Climate Change. Energy Procedia, v.18, p.507-520, 2012. Doi: http:// dx.doi.org/10.1016/j.egypro.2012.05.062

SHEWEKA, S.; MAGDY, A.N. The Living walls as an approach for a healthy urban environment. Energy Procedia, v.6, p.592-599, 2011. Doi: http://dx.doi. org/10.1016/j.egypro.2011.05.068

SINGH, A.M.S.; SYAL, M.P.; GRADY, S.C.P.M.P.H.; KORKMAZ, S.P. Effects of Green Buildings on Employee Health and Productivity. American Journal of Public Health, v.100, n.9, p.1665-1668, 2010.

SODERLUND, J. Biophilic design: a social movement journey. (Doctorate of Philosophy), Curtin University, Perth, Western Australia, 2016.

SODERLUND, J.; NEWMAN, P. Biophilic architecture: a review of the rationale and outcomes. AIMS Environmental Science, v.2, n.4, p.950-969, 2015. Doi: http://dx.doi.org/10.3934/environsci.2015.4.950
SPROUL, J.; WAN, M.P.; MANDEL, B.H.; ROSENFELD, A.H. Economic comparison of white, green, and black flat roofs in the United States. Energy and Buildings, v.71, p.20-27, 2014. Doi: http://dx.doi.org/10.1016/j. enbuild.2013.11.058

STEINER, F.R. Design for a vulnerable planet. USA: University of Texas Press, 2011.

STOREY, D.; KANG, K.K.P. Planning for sustainable and low carbon green cities. In: LEHMANN, S. Low carbon cities. Oxon: Routledge, 2015.

SUSCA, T.; GAFFIN, S.R.; DELL'OSSO, G.R. Positive effects of vegetation: urban heat island and green roofs. Environmental Pollution, v.159, n.8-9, p.2119-2126, 2011. Doi: http://dx.doi.org/10.1016/j.envpol.2011.03.007

TAN, A.; CHIANG, K.; CHAN, D.; WONG, N.; CHEN, Y.; TAN, A.; WONG, N. Vertical Greenery for the Tropics: NParks, 2009.

TAN, P.Y. Vertical Garden City: Singapore. Singapore: Straits Times Press Pte Ltd, 2013.

TAYLOR, R.P. Reduction of physiological stress using fractal art and architecture. Leonardo, v.39, n.3, p.245$251,2006$.

TENNGART IVARSSON, C.; HAGERHALL, C.M. The perceived restorativeness of gardens - Assessing the restorativeness of a mixed built and natural scene type. Urban Forestry \& Urban Greening, v.7, n.2, p.107-118, 2008. Doi: http://dx.doi.org/10.1016/j.ufug.2008.01.001

TYRVÄINEN, L.; OJALA, A.; KORPELA, K.; LANKI, T.; TSUNETSUGU, Y.; KAGAWA, T. The influence of urban green environments on stress relief measures: a field experiment. Journal of Environmental Psychology, v.38, p.1-9, 2014. Doi: http://dx.doi.org/10.1016/j. jenvp.2013.12.005

ULRICH, R.S. Visual landscapes and psychological wellbeing (National Parks). Landscape Research, v.4, n.1, p.17-23, 1979.

ULRICH, R.S. View through a window may influence recovery from surgery. Science, v.224, n.4647, p.420-421, 1984.

ULRICH, R.S. Essay: Evidence-based health-care architecture. The Lancet, v.368, S38-S39, 2006. 
ULRICH, R.S.; SIMONS, R.F.; LOSITO, B.D.; FIORITO, E.; MILES, M.A.; ZELSON, M. Stress recovery during exposure to natural and urban environments. Journal of Environmental Psychology, v.11, n.3, p.201-230, 1991. Doi: http://dx.doi.org/10.1016/S0272-4944(05)80184-7

WILSON, E.O. Biophilia. Massachusetts: Harvard University Press, 1984.

WILSON, E.O. The nature of human nature. In: KELLERT, S.R.; WILSON, E.O. (Eds.). Biophilic design. New Jersey: John Wiley \& Sons, 2008. pp. 21-25.

WOLF, K. Trees in the small city retail business district: Comparing resident and visitor perceptions. Journal of Forestry, v.103, n.8, p.390-395, 2005.
WOLVERTON， B.;MCDONALD， R.; WATKINS, E. Foliage plants for removing indoor air pollutants from energy-efficient homes. Economic Botany, v.38, n.2, p.224-228, 1984. Doi: 10.1007/BF02858837

WONG, N.H.; KWANG TAN, A.Y.; CHEN, Y.; SEKAR, K.; TAN, P.Y.; CHAN, D.; CHIANG, K.; WONG, N.C. Thermal evaluation of vertical greenery systems for building walls. Building and Environment, v.45, n.3, p.663-672, 2010. doi: http://dx.doi.org/10.1016/j. buildenv.2009.08.005 